\title{
The Iran-Iraq War has to end
}

Ezzat Abouleish, M.D.,

Houston, Texas.

DOI: http://dx.doi.org/10.5915/20-2-13081

Last week I spoke to a friend about the Middle East, about the Muslim countries, and about the Iran-Iraq war. I said, "This war has to stop and I must do something about it." My friend asked, "Do you know the problem, do you know the details of this bloody war?" My answer was, "No I do not. If I had known I would have found an excuse for the war to continue. All that I know is this war is senseless, it is against the basic and fundamental teachings of Islam, it is against humanity, and it has to stop." $\mathrm{He}$ asked, "How can you stop it? Who are you? Respectful organizations such as the Organization of Islamic Conference, and more important people such as the Secretary General of the U.N. have failed. Why do you think you will succeed?" I said, "The Organization of Islamic Conference is considered by those fighting as not representing the Nation of Islam, but instead representing politicians on the top, while the Secretary General speaks a diplomatic language. I am not a politician, I am not a diplomat; $\mathrm{I}$ am a human being, I am a Muslim. Islam is in my heart, and my heart bleeds for my brothers in Iraq and Iran". He said, "Why not enjoy your life and enjoy what God provided for you. You do not live in the Middle East. You are not even an Iraqi nor an Iranian." I said, "The color of the shedded blood is the same as mine, and those whose blood is flowing in the battlefields, in the bombed towns, in the ravaged villages are my brothers. How can I close my eyes and ears? Islam has no boundaries, no borders. I will speak from my heart to the heart of the leaders of both countries. I have nothing to gain except the acceptance and the blessings of God. I do not work for a country and I am not paid by any person. I spend a life full of actions, good and bad; full of achievements, great and small. What time is left for me is not too long, definitely less than what I have spent. Eventually I will meet the Almighty God. He will then ask me what did you do with your life?.I

From the Department of Anesthesiology, The University of Texas Health Science Center at Houston, Houston, TX 77030

Reprint request: Department of Anesthesiology, The University of Texas Health Science Center at Houston, Houston, TX 77030.

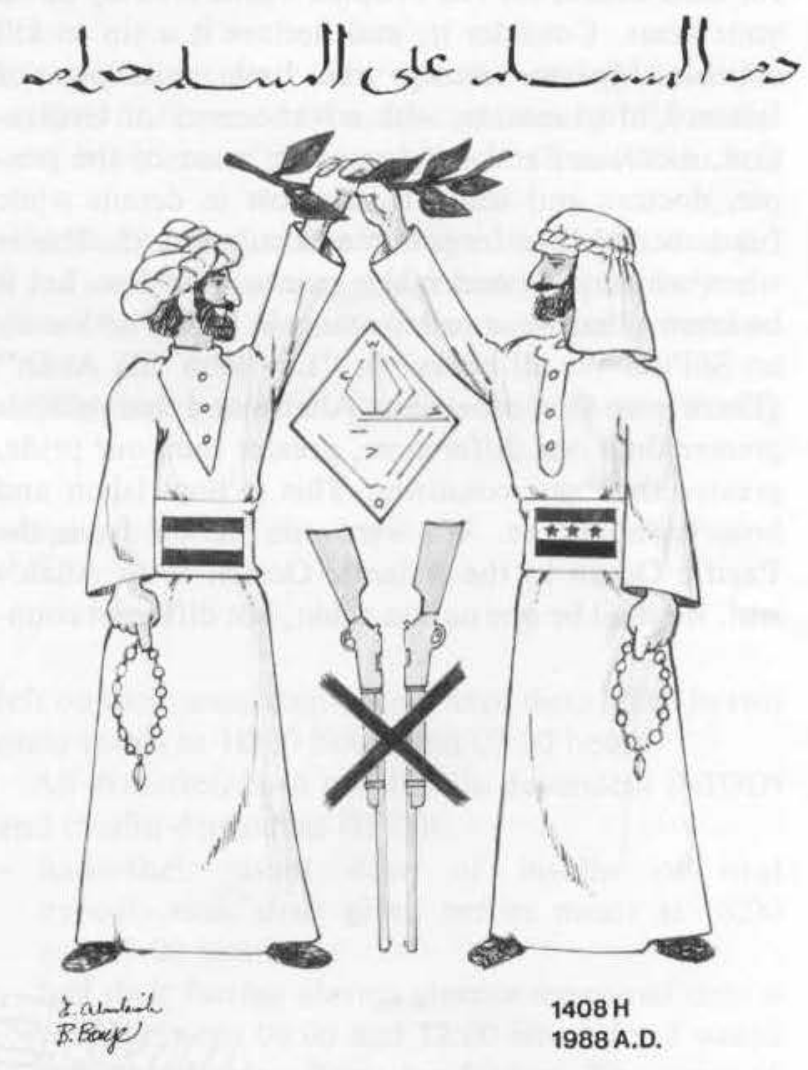

"The shedding of a Muslim's blood by another Muslim is a sin" From the Prophet's Farewell Sermon

want to answer: Lord, I tried my best to be a good physician. I am sure that I saved some lives. But my work as a physician was to take care and try to save one life at a time. My Lord, I decided that the time has come, to save more lives at one time, thousands of them. We were taught in medical schools and we now preach to our students that prophylaxis is better than treatment. Therefore, I thought it is better to stop the war than to treat the wounded. Many of them die before medicl help can reach them and others expire despite medical efforts. Working for you, instead of working for a hospital or an institution, was a better achievement. I brought, instead of tears and sadness, smiles to faces of mothers, children, and wives of my fellow men. My Lord, I brought prosperity instead of destruction. I left behind factories, schools, cities full of happiness, 
productivity and people glorifying you, insted of asking questions "Why me God? Why me?" You did create life and I did my best to preserve it. My Lord, I was on your side. Would you forgive me? Would you? That is why and what I want to do."

The last wrods of the Prophet (PBUH) were: "The shedding of a Muslim's blood by another Muslim is a sin." There is no more explicit, or more direct wording to defy this bloody was than these words. All that I want from you my brothers in Iran and Iraq, for God's sake, for His Prophet's sake is to lay down your arms. Consider it, and declare it a sin to kill another Muslim. Accept the basic principles of Islam. Unfortunately, with advancement of civilization, medicine, and religion alike, most of the people, doctors and students, are lost in details while fundamentals are forgotten and submerged. This is when we stumble and make serious mistakes. Let it be known that we are all brothers in Islam, no Sunni, no Shi'ite. We all believe in "Lã 'ilāha 'illā Allāh" (There is no God other than Alläh), and that Allāh is greater than our differences, greater than our pride, greater than our countries. This is how Islam and how it should be. We were one nation from the Pacific Ocean to the Atlantic Ocean. With Allāh's will, we shall be one nation again, not different coun- tries fighting and killing each other. This fragmentation is artificial, made by our enemies to weaken us. They brought unto us hatred for our brothers. Allah said, "We made you nations and tribes to know each other." He did not say... to fight and kill each other. Our enemies supply us with weaponry saying "let them kill each other; otherwise they will turn on to us". They provoke, cultivate, arouse in us the feeling of hatred and revenge. They follow the rule of divide and conquer. Are they afraid of Islam? We mean no harm. We want peace, love, and prosperity on earth. Let the whole world realize that we hve no ambition to conquer more land. Thank God, we are more than 900 million strong. We hold a strategic position in the world, and we have the highest resources. All that is needed is for our people to come to their senses and not to fall into the traps of the enemies of Islam.

Let the world witness that our slogan is "One God, One Nation". We will say no to hatred. We will say no to killing. We will say no to war. We will say yes to peace. We will say yes to love. We will say yes to Islam. We will say "Our Lord, we are answering your call. We are coming forward to you. You are the Lord without any partners. We are answering your call." 